\title{
STRUKTUR ANATOMIS VALVULA INTESTINALIS PARI GITAR (Rhinobatos typus)
}

\author{
Kusrini' $^{1)}$, La Aba ${ }^{2)}$ \\ ${ }^{1,2)}$ Progam Studi Pendidikan Biologi, FKIP Universitas Muhammadiyah Buton \\ ${ }^{1)}$ email: kusrinigamzaa@gmail.com
}

Diterima 30 Maret 2019 disetujui 3 Mei 2019

\begin{abstract}
Rhinobatos typus is included in Elasmobranchii Subclasses which has a unique intestine structure on internal part forms folds called valvula intestinalis as extension surface of food absorption. The uniqueness is influenced by habitat differences and food types. Ray's habitat is in all waters, one of them is in waters Wakatobi Island. The aims of this research to determine Rhinobatos typus anatomical structure variations of valvula intestinalis were decided by observing intestine internal folds variations. Microanatomy structures were performed by making histological preparations using paraffin method, NBF (netral buffer formalin) solution fixation with Hematoxilin-Eosin (HE) staining. The result of the research indicated microanatomis structures of Rhinobatos typus has valvula intestinalis in spiral-shaped. Microanatomic structures of both internals valvula intestinalis from outside to inside consists of mucosa, submucosa, and muscularis.
\end{abstract}

Keyword : Rhinobatos typus, anatomical structurer, valvula intestinalis

\section{PENDAHULUAN}

Pari termasuk dalam Subkelas Elasmobranchii yang rangka tubuhnya tersusun oleh tulang rawan, sehingga dikelompokkan kedalam Kelas Chondrichthyes (Walker, 2005). Ciri umum anggota Subkelas Elasmobranchii adalah memiliki sisik placoid, mengalami pergantian gigi, serta memiliki celah insang 5-7 pasang. Celah insang pari terletak di sisi ventral kepala (Manik, 2003). Celah insang tersebut tidak dilengkapi tutup insang (operculum). Sirip dada ikan pari hampir selalu melebar menyerupai sayap, sisi depannya bergabung dengan sisi kepala (Manik, 2003). Sirip ekor pada Pari mengalami pemanjangan menyerupai cambuk (Kardong, 2009).

Pari Gitar (Rhinobatos typus Bennett, 1830) merupakan anggota Elasmobranchii yang ditemukan di perairan laut sebelah selatan pulau Jawa, yakni di laut sebelah Selatan
Jawa (Fahmi \& Dharmadi, 2013). Selain itu juga, Pari ditemukan di perairan Banda hingga di peraian Wakatobi. Umumnya, spesies tersebut mendiami dasar perairan, juvenilnya banyak ditemukan di sekitar perairan pantai hutan bakau dan pulau karang, sedangkan dewasanya ditemukan lebih kearah lepas pantai pada kedalaman 100 meter. Makanannya berupa anggota Crustacea dan kelompok cumi (White et al., 2006).

Perbedaan habitat dan jenis makanan yang dikonsumsi oleh spesies ini menyebabkan terjadinya variasi atau modifikasi struktur intestinum, yaitu cara perluasan pencernaan dan penyerapan makanan. Menurut Walter \& Sayles (1961), anggota

Subkelas Elasmobranchii memiliki cara perluasan pencernaan dan penyerapan makanan dengan pembentukan lipatan internal intestinum. Daniel (1934) menyatakan 
bahwa lipatan tersebut disebut valvula intestinalis, ada yang berbentuk gulungan kertas dan ada pula yang berbentuk spiral. Oleh karena itu, penelitian mengenai struktur anatomi valvula intestinalis perlu dilakukan, yakni untuk mengetahui struktur makroanatomis dan mikroanatomis valvula intestinalis. Dengan demikian dapat dijadikan sebagai dasar penelitian lanjutan.

\section{METODE}

Penelitian ini bersifat eksperimen murni (pure eksperimen) dengan kondisi Laboratorium. Ruang lingkup penelitian ini mengenai sturktur makroanatomis dan struktur mikroanatomis valvula intestinalis Pari Gitar (Rhinobatos typus; Bennett, 1830). Penelitian dilaksanakan pada bulan Agustus sampai Desember 2018, di Laboratorium IPA Dasar Universtas Muhammadiyah Buton.

Subyek penelitian berupa Pari Gitar (Rhinobatos typus; Bennett, 1830) sebanyak empat (4) individu dengan ukuran tubuh yang berbeda-beda. Prosedur penelitian ini dilakukan di Laboratorium IPA Dasar UM Buton melalui 3 (tiga) tahap, diantaranya :

1. Observasi

Observasi lokasi pengambilan sampel di penangkaran ikan Kecamatan Wangi-wangi Kabupaten Wakatobi. Pengambilan sampel sebanyak 4 (empat) individu dengan ukuran tubuh yang berbeda-beda.

2. Pembuatan Preparat

Makroanatomis

Valvula Intestinalis

Pembuatan preparat

makroanatomis valvula intestinalis

dilakukan dengan metode

pembedahan (Iuliis \& Pelura,
2007). Pengamatan preparat makroanatomis meliputi : mengukur panjang tubuh dan panjang saluran pencernaan, variasi bentuk valvula intestinalis, jumlah gulungan pada valvula intestinalis yang berbentuk gulungan dan jumlah ulir pada valvula intestinalis berbentuk spiral, dan luas kedua permukaan valvula intestinalis baik berbentuk gulungan kertas maupun berbentuk spiral.

3. Pembuatan Preparat Mikroanatomis Valvula intestinalis Pembuatan preparat mikroanatomis valvula intestinalis dilakukan dengan metode parafin, fiksatif NBF (netral buffer formlin) dengan pewarnaan HematoxilinEosin (Brancroft \& Cook, 1984). Pengamatan preparat mikroanatomi meliputi: pengamatan empat tunika pada valvula intestinalis dan mengukur tinggi vili (villus) pada permukaan tunika mukosa.

Pari yang diperoleh dari penangkaran ikan diidentifikasi karakter morfologinya berdasarkan Carpenter \& Niem (1999), Nelson (2006), dan White et al. (2006). Pengamatan preparat makroanatomis meliputi: mengukur panjang tubuh dan panjang saluran pencernaan, variasi bentuk valvula intestinalis, jumlah gulungan pada valvula intestinalis yang berbentuk gulungan dan jumlah ulir pada valvula intestinalis berbentuk spiral, dan luas kedua permukaan valvula intestinalis baik berbentuk gulungan kertas maupun berbentuk spiral. Pengamatan preparat mikroanatomis dilakukan dengan metode parafin, fiksatif NBF dengan pewarnan Hematoxilin-Eosin (Brancroft 
\& Cook, 1984). Pengamatan

preparat mikroanatomi meliputi: pengamatan empat tunika pada valvula intestinalis dan mengukur tinggi vili (villus) pada permukaan tunika mukosa.

Data yang diperoleh pada pengamatan preparat makroanatomis dianalisis secara deskriptif komparatif, yaitu mendeskripsi dan membandingkan ukuran panjang tubuh dan panjang saluran pencernaan masing-masing individu, variasi bentuk valvula intestinalis, jumlah gulungan dan atau ulir valvula intestinalis dan luas kedua permukaan valvula intestinalis masingmasing individu. Data pengamatan preparat mikroanatomis dianalisis secara deskriptif, yaitu mendeskripsi struktur histologis valvula intestinalis, tinggi vili (villus) valvula intestinalis.

\section{HASIL DAN PEMBAHASAN}

\section{Morfologi Pari Gitar (Rhinobatos typus;Bennett, 1830)}

Rhinobatos typus disebut pula Pari Gitar. Bentuk tubuh dorsoventral, melebar kearah lateral seperti bentuk cakram. Tubuh bagian dorsal berwarna coklat, sedangkan bagian ventral berwarna putih. Panjang tubuh berkisar $55-72,5 \mathrm{~cm}$, lebar tubuh berkisar 20$26,5 \mathrm{~cm}$. Moncong spesies ini berukuran panjang, pada bagian ujungnya membentuk sudut lancip (meruncing) dengan kisaran panjang 12,2-14,8 cm. Bentuk kepala spesies ini memipih, pada bagian sisi lateralnya bergabung dengan sirip dada. Pada bagian dorsal kepala pari ini terdapat sepasang mata dan sepasang spirakel. Celah spirakel terletak tepat pada bagian posterior mata. Keunikan spirakel spesies ini ialah salah satu sisi celahnya terdapat dua tonjolan kulit dengan ukuran yang berbeda.

\section{Struktur Makroanatomi Valvula Intestinalis}

Pengamatan

struktur makroanatomis valvula intestinalis meliputi ukuran panjang tubuh, panjang saluran pencernaan, bentuk variasi, arah putaran, jumlah putaran, panjang dan lebar serta luas valvula intestinalis masing-masing individu.

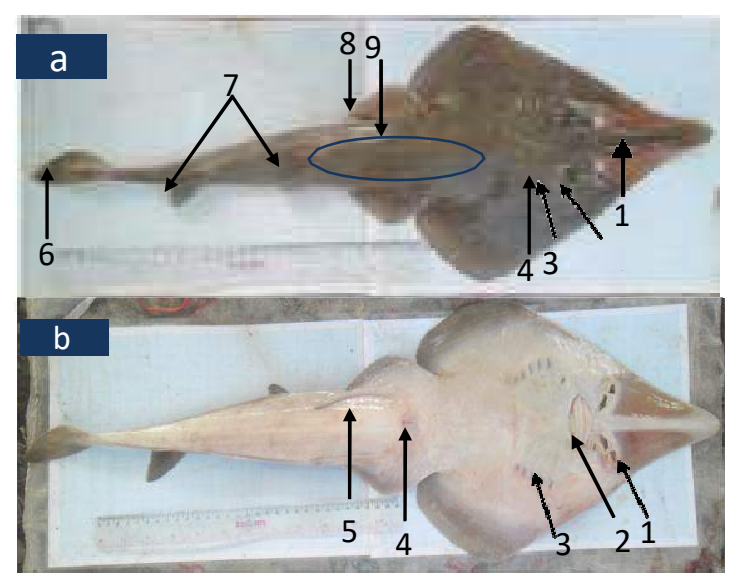

Gambar 1. Bagian Tubuh Pari Gitar (Rhinobatos typus); a) Bagian dorsal tubuh:

1. Moncong; 2. Mata; 3. Spirakel; 4. Tonjolan kulit pada spirakel; 5. Sirip dada; 6. Sirip ekor;7. Sirip punggung; 8. Sirip perut; 9.

Dentikel; b) Bagian ventral tubuh : 1. Nostril; 2. Celah mulut; 3. Celah insang; 4. Celah kloaka;

5. Clasper.

Sirip dada spesies ini melebar menyatu dengan sisi kepala. Selain memiliki sepasang sirip dada, spesies ini perut. Sepasang sirip punggung juga dimiliki oleh spesies ini, sirip punggung pertama lebih dekat dengan sirip perut sedangakn sirip punggung kedua lebih dekat dengan sirip ekor. Ekor spesies ini memanjang ke arah posterior, berdaging dan tidak seperti cambuk. Sirip ekor pendek dan membulat, cuping sirip ekor bagian dorsal lebih tinggi dibanding cuping sirip ekor bagian ventral. Sirip ekor tidak dilengkapi organ listrik. 
Hasil pengamatan struktur makroanatomis valvula intestinalis pada Pari Gitar (Rhinobatos typus) dapat dilihat pada Tabel 1. Data pengamatan pada Tabel 1 menunjukkan bahwa semakin panjang ukuran panjang tubuh, semakin panjang pula ukuran panjang saluran pencernaan masing-masing individu. Ukuran panjang saluran pencernaan akan bertambah seiring bertambahnya panjang tubuh. Steffens (1989) menyatakan bahwa pertambahan panjang organ pencernaan ikan sejalan dengan meningkatnya ukuran panjang total tubuh ikan. Panjang pendek saluran pencernaan dipengaruhi pula oleh jenis makanan yang dikonsumsi. Berdasarkan hasil pengamatan, vetrikulus Pari Gitar terdapat potongan udang kecil yang telah bercampur dengan cairan digestif. Oleh karena itu, Pari Gitar dikelompokkan kedalam anggota ikan Carnivora. Organ pencernaan Pari Gitar dapat dilihat pada Gambar 2.

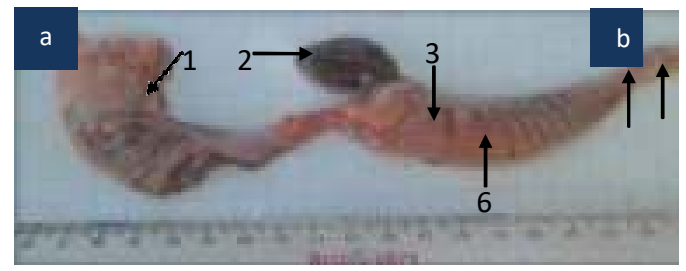

Gambar 2. Organ pencernaan Pari Gitar $(R$. typus); a) Anterior; b) Posterior; 1. Esofagus; 2. Limpa; 3. Dinding intestinum; 4. Cloaca; 5. Rectum; 6. Garis antar valvula.

Tabel 1. Hasil pengamatan struktur makroanatomis valvula intestinalis berbentuk spiral pada Pari Gitar ( $R$. typus)

\begin{tabular}{|c|c|c|c|c|c|c|c|}
\hline Ind. & $\begin{array}{c}\text { Panjang } \\
\text { tubuhl(cm) }\end{array}$ & $\begin{array}{l}\text { Pamjang saluran } \\
\text { pencernaan }(\mathrm{cm})\end{array}$ & $\begin{array}{l}\text { Jumlah } \\
\text { ulir }\end{array}$ & $\begin{array}{c}\text { Panjang } v i f \\
\text { (cm) }\end{array}$ & $\begin{array}{c}\text { Lebar } \\
v i f(\mathrm{~cm})\end{array}$ & $\begin{array}{l}\text { Luas vif } \\
\left(\mathrm{cm}^{2}\right)\end{array}$ & $\begin{array}{l}2 \times \text { Luas } \\
v \cdot i\left(\mathrm{~cm}^{2}\right)\end{array}$ \\
\hline I & 55 & 24,4 & 5 & 19 & 4,33 & 82,27 & 164,54 \\
\hline II & 69 & 26 & 5 & 20,3 & 4,07 & 82,62 & 165,24 \\
\hline$ш$ & $1 / 2,3$ & 28,1 & 3 & 20,3 & 4,57 & 93.09 & $18 /, 3 /$ \\
\hline Jlh & 196,5 & 78,5 & 15 & 59,8 & 12,97 & 258,58 & 517,05 \\
\hline Rerata & 65,5 & 26,17 & 5 & 19,93 & 4,32 & 86,19 & 172,35 \\
\hline
\end{tabular}

Ket. Ind. = Individu; $v \cdot i=$ valvula intestinalis

Salah satu ciri anggota Carnivora, ukuran saluran pencernaan makanan lebih pendek daripada ukuran panjang total tubuh. Hal tersebut tidak mengurangi fungsi saluran pencernaan jenis ikan tersebut dalam mencerna dan menyerap sari-sari makanan. Sebab, intestinum Pari Gitar mengalami modifikasi, yaitu pada bagian internal intestinum terdapat lipatan yang disebut valvula (valvula intestinalis). Menurut Carvalho (2014), valvula intestinalis pada anggota Elasmobranchii ada yang berbentuk spiral dan ada pula yang berbentuk gulungan kertas.
Perbedaan bentuk valvula intestinalis dapat dipengaruhi oleh bentuk tubuh dan rongga perut masing- masing spesies ikan. Valvula intestinalis merupakan lipatan internal intestinum yang berperan dalam perluasan permukaan pencernaan dan penyerapan makanan tanpa menambah ukuran dan bentuk luar saluran pencernaan (Walter \& Sayles, 1961). Dengan demikian, ukuran diameter saluran pencernaan tidak berubah, namun pada bagian internalnya terjadi lipatan berupa spiral. 


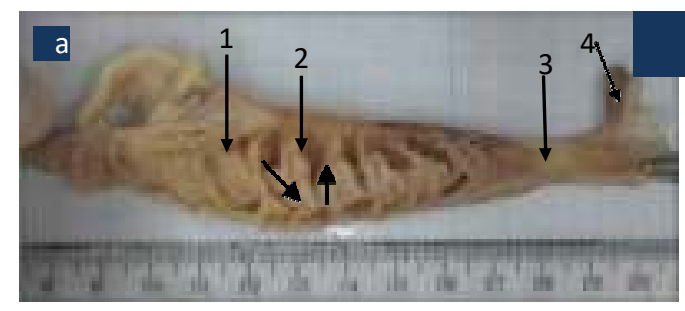

Gambar 3. Valvula intestinalis Bentuk Spiral pada Pari Gitar (Rhinobatos typus) Anterior; b) Posterior; 1. Sisi pemula valvula intestinalis; $2 . \quad$ Valvula intestinalis; 3. Dinding intestinum; 4. Colon; 5. Gland rectum;6. Cloaca;

Hasil pengamatan (Gambar 3.) menunjukkan bahwa valvula intestinalis Pari Gitar berbentuk spiral. Speseis ini memiliki bentuk tubuh melebar ke arah lateral, sehingga rongga perutnya lebih sempit. Intestinum spesies ini sempit dan pendek mengikuti rongga perut. Perluasan area pencernaan dan penyerapan makanan dengan pembentukan lipatan yang melingkar membentuk spiral. Valvula intestinalis berbentuk spiral mempunyai struktur seperti anak tangga bentuk spiral. Salah satu sisi valvula berhimpit dengan dinding internal intestinum, sedangkan sisi lainnya bebas, melingkar membentuk anak tangga berbentuk spiral. Sisi pemula valvula berhimpit dengan dinding internal intestinum sebelah kanan, selanjutnya mengarah ke kanan dinding intestinum, demikian seterusnya hingga membentuk corong valvula. Dengan demikian dapat diketahui arah putaran lipatan tersebut yaitu berlawanan arah jarum jam. Artinya bahwa makanan yang berasal dari ventriculus mengikuti arah putaran valvula menuju ke intestinum. Valvula intestinalis bentuk spiral pada Pari Gitar ditunjukkan pada Gambar 3.

Jumlah ulir (lembar) pada valvula spiralis anggota Elasmobrnchi berbedabeda. Pari Gitar mempunyai jumlah ulir valvula intestinalis sebanyak 5 (lima).
Jumlah ulir valvula pada anggota Elasmobranchii dipengaruhi pula oleh aktivitas spesies yang mendiami habitat tertentu. Pari Gitar yang biasa ditemukan mendiami dasar perairan berlumpur atau berkarang merupakan spesies pari yang aktivitasnya rendah dibanding pari lainnya atau anggota Elasmobranchii lainnya. Semakin tinggi aktivitas suatu individu, semakin besar pula energi yang dibutuhkan. Oleh karena itu, untuk mencukupi kebutuhan energi, suatu individu memerlukan sumber makanan yang banyak. Selain itu, untuk mengefisienkan waktu dan tempat, organ pencernaan tersebut dimodifikasi untuk memaksimalkan pencernaan dan penyerapannya. Modifikasi organ tersebut berupa lipatan (disebut valvula) pada bagian internal intestinum dengan jumlah yang banyak. Dengan demikian, jumlah valvula pada valvula spiralis hanya 5 (lima) lembar.

Luas permukaan valvula intestinalis (Tabel 1) menunjukkan bahwa semakin besar ukuran tubuh individu, semakin besar pula perluasan organ pencernaan dan penyerapan makanan yang diperlukannya. Menurut Cao \& Wang (2009), bentuk anatomi intestinum spesies dipengaruhi oleh makanan, cara makan, bentuk tubuh dan usia. Pari Gitar yang memiliki bentuk tubuh pipih kearah lateral, memiliki bentuk permukaan luar intestinum yang semakin ke arah posterior ukuran diameternya semakin kecil. Oleh karena itu, ukuran lebar valvula spiralis yang dimiliki oleh pari Gitar semakin ke posterior semakin kecil. Lebar valvula pada anterior valvula spiralis pari Gitar dua kali lebar valvula pada posterior valvula spiralis. 


\section{Struktur Mikroanatomis Valvula Intestinalis}

Valvula intestinalis merupakan lipatan pada bagian internal intestinum anggota Elasmobranchii, yakni hiu dan pari. Organ tersebut berperan dalam perluasan pencernaan dan penyerapan sari-sari makanan. Hasil pengamatan struktur mikroanatomis menunjukkan bahwa pada kedua permukaan valvula intestinalis pari Gitar ( $R$. typus) dari luar ke dalam tersusun atas tunika mukosa, tunika submukosa dan tunika muskularis tanpa adanya tunika serosa (Gambar 4). Tunika mukosa valvula intestinalis tersebut tersusun oleh selapis sel epitel kolumner yang melapisi villi intestinalis.

Menurut Khan \& Nasimul (2012), vili (villus) merupakan penonjolan lipatan epitel kearah lumen intestinum, bagian sebelah dalamnya terdapat lamina propia. Berdasarkan Tabel 2, villi intestinalis pada Pari Gitar terletak pada kedua sisi valvula intestinalis. Pari Gitar mendiami dasar perairan berlumpur atau berkarang, biasanya memakan udang- udangan. Spesies tersebut juga memiliki cara perluasan pencernaan dan penyerapan makanan dengan pembentukan valvula spiralis yang memiliki villi intestinalis tersusun lebih rapat dan memiliki ukuran tinggi yang sama. Selain itu, Pari Gitar memiliki keunikan valvula spiralis, yaitu pada kedua sisi valvula terdapat percabangan villi intestinalis. Pada Mamal, percabangan villi intestinalis ditemukan pada bagian jejunum. Bagian tersebut memiliki peranan pencernaan dan penyerapan yang lebih tinggi dibandingkan dengan bagian intestinum lainnya. Hal ini memunjukkan bahwa peranan valvula spiralis pada pari Gitar dalam perluasan pencernaan dan penyerapan makanan lebih maksimal.

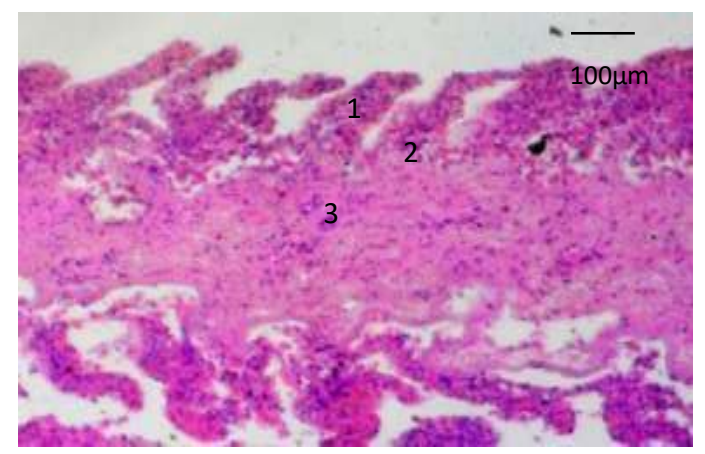

Gambar 4. Struktur mikroanatomis Valvula spiralis pada pari Gitar (R. typus); Penampang melintang; Tebal irisan : $6 \mu \mathrm{m}$; Pewarnaan $\mathrm{H}-$ E; Perbesaran 10 x 10; 1. Villi intestinalis; 2 . Tunika submukosa; 3 . Tunika muskularis.

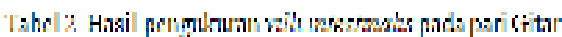

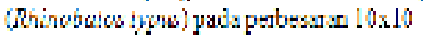

\begin{tabular}{|c|c|c|c|}
\hline $8: 12.2$ & Lus: & 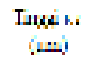 & 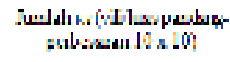 \\
\hline Zaiki.a & בخدu' & 40 & 12 \\
\hline
\end{tabular}

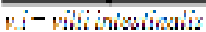

Luas paudany yerbesaran $10 \times 10-$ -.$x^{2}$

$\left(3.11 \times(310 \mu=)^{2}\right)-362981 \mu=0.26$

$\mathrm{min})^{2}$

Menurut Khan \& Nasimul (2012), vili (villus) merupakan penonjolan lipatan epitel kearah lumen intestinum, bagian sebelah dalamnya terdapat lamina propia. Berdasarkan Tabel 2, villi intestinalis pada Pari Gitar terletak pada kedua sisi valvula intestinalis. Pari Gitar mendiami dasar perairan berlumpur atau berkarang, biasanya memakan udang- udangan. Spesies tersebut juga memiliki cara perluasan pencernaan dan penyerapan makanan dengan pembentukan valvula spiralis yang memiliki villi intestinalis tersusun lebih rapat dan memiliki ukuran tinggi yang sama. Selain itu, Pari Gitar memiliki keunikan valvula spiralis, yaitu pada kedua sisi valvula terdapat percabangan villi intestinalis. Pada Mamal, percabangan villi intestinalis ditemukan pada bagian jejunum. Bagian tersebut 
memiliki peranan pencernaan dan penyerapan yang lebih tinggi dibandingkan dengan bagian intestinum lainnya. Hal ini memunjukkan bahwa peranan valvula spiralis pada pari Gitar dalam perluasan pencernaandan penyerapan makanan lebih maksimal.

Pada pengamatan villi intestinalis, tidak terlihat adanya sel Goblet di sekitar sel epitel mukosa. Menurut Khan \& Nasimul (2012) bahwa pada sel epitel mukosa juga terdapat sel Goblet. Sel Goblet berfungsi mensekresi cairan mukus yang melindungi tunika mukosa. Meskipun tidak terdapat sel Goblet pada villi intestinalis Pari Gitar, namun pada villi intestinalis spesies tersebut nampak terlihat sel-sel mukus yang terwarnai oleh H-E. Sel-sel tersebut merupakan sel-sel penghasil cairan mukus yang berperan dalam pencernaan dan penyerapan makanan serta melindungi permukaan tunika mukosa. Selain itu, juga terdapat lamina propia tersusun oleh jaringan ikat yang banyak terdapat pembuluh darah dan pembuluh saraf. Lamina propia pada villi intestialis Pari Gitar berupa celah memanjang diantara selsel epitel.

Sisi sebelah dalam villi intestinalis terdapat lapisan otot tipis memanjang, disebut muskularis mukosa. Muskularis mukosa membatasi tunika mukosa dengan tunika submukosa yang terletak pada sisi sebelah dalamnya. Tunika submukosa valvula intestinalis yang dimiliki oleh ketiga individu Pari Gitar ini merupakan jaringan ikat tipis yang terletak pada masing-masing sisi sebelah dalam tunika mukosa. Sisi sebelah dalam tunika submukosa berbatasan dengan lapisan otot tipis. Lapisan otot membentuk lapisan (tunika) yang disebut tunika muskularis. Tunika muskularis pada salah satu sisi valvula intestinalis berhimpitan dengan tunika muskulari pada sisi valvula intestinalis lainnya, sehingga tidak terdapat tunika serosa.

\section{SIMPULAN}

Struktur makroanatomis valvula intestinalis Pari Gitar (Rhinobatos typus) memiliki valvula intestinalis berbentuk spiral dengan lima lembar valvula. Pari Gitar memiliki valvula intestinalis yang semakin ke posterior, semakin kecil. Struktur mikroanatomis kedua permukaan valvula intestinalis Pari Gitar tersusun dari luar ke dalam mukosa, submukosa, dan muskularis.

\section{DAFTAR PUSTAKA}

Brancroft, J.D. \& Cook, H.C. 1984. Manual of Histological Techniques. Churchill Livingstone. Edinburgh London Melbourne and New York.

Cao, X.J. \& Wang, W.M. 2009. Histology and Mucin

Histochemistry of The Digestive Tract of Yellow Catfish, Pelteobagrus fulvidraco. Anat. Histol. Embryol. 382 : 54-261.

Daniel, J.F. 1934. The Elasmobranch Fishes. University of California Press. Berkeley. California.

Iuliis, G.D. \& Pulera, D. 2007. The Dissection of Vertebrates A Laboratory Manual. Elsevier. London

Kardong, K.V. 2009. Vertebrates Comparative Anatomy, Function, Evolution. Mc Graw Hill. Washington State University.

Khan, J. \& Nasimul, I.M. 2012. Morphology of the Intestinal Barrier in Different Physiological and Pathological Conditions. DOI.org/10.5772/50659. Diakses tanggal 3 Februari 2019. 
Manik, N. 2003. Beberapa Catatan Mengenai Ikan Pari. Oseana, Volume XXVIII, Nomor 4 : 17-23.

Nelson, J.S., 2006. Fish Of The World fourth Edition. University of Alberta. Canada.

Walker, T.I. 2005. General Biology of Chondrichthyan Fishes. Marine and Freshwater Systems. Victoria. Australia. White, W.T., Last, P.R. \& Yearsley, G.K. 2006. Economically Important Sharks and Rays Indonesia. Murdoch University. Australia.

Walter, H.E. \& Sayles, L.P. 1961. Biology of The Vertebrates. Priting Macmillan Company. New 